\title{
ADAPTASI LATIHAN JUDO DI MASA PANDEMI COVID-19
}

\author{
Ira Purnamasari ${ }^{1}$, Mona Fiametta Febrianty ${ }^{2}$ \\ ${ }^{1}$ Program Studi Pendidikan Kepelatihan Olahraga, Universitas Pendidikan Indonesia, \\ Indonesia \\ ${ }^{2}$ Program Studi Kepelatihan Fisik Olahraga, Universitas Pendidikan Indonesia, \\ Indonesia
}

e-mail: $\underline{\text { rapurnamasari@upi.edu, monafiametta@upi.edu }}$

\begin{abstract}
Abstrak
Covid-19 membuat hampir seluruh masyarakat merasa takut untuk berinteraksi, tidak terkecuali dalam kegiatan berolahraga. Namun pada masa sekarang yang telah memasuki masa Adaptasi Kebiasaan Baru (AKB), sejumlah protokol kesehatan telah dibuat oleh WHO maupun Pemerintah guna menekan angka penularan Covid-19. Judo sebagai salah satu cabang olahraga memiliki aturan protokol kesehatan dalam pelaksanaan latihan yang dikeluarkan oleh International Judo Federation (IJF). Tujuan dari penelitian ini adalah untuk melihat apakah club judo di Indonesia telah mengikuti protokol kesehatan yang dikeluarkan oleh IJF dalam pelaksanaan latihan pada masa Pandemi Covid-19. Penelitian ini menggunakan metode deksriptif. Instrumen penelitian menggunakan angket mengenai protokol kesehatan yang dikeluarkan oleh IJF. Populasi yang digunakan dalam penelitian ini adalah seluruh klub Judo di Indonesia. Sedangkan sample penelitiannya berjumlah 28 klub Judo. Hasil dari penelitian ini adalah hampir seluruh club yang melaksanakan latihan pada masa pandemi Covid 19 ini telah melaksanakan protokol kesehatan dari IJF.
\end{abstract}

Kata-kata kunci: Covid-19, Judo, Protokol Kesehatan

\begin{abstract}
Covid-19 has been terrifying people to interact, including doing sports activities. However, within the new normal, a number of health and safety protocols has been made by either the WHO or the government in order to reduce the increase of COVID19 spread. To this relation, Judo has its own rules and protocols of training released by the International Judo Federation (IJF). The purpose of this study is to identify whether the Indonesian judo club follows the health and safety protocols by the IJF during the training amid the global pandemic. This study used a descriptive research method and the instrument used was a questionnaire about health and safety protocols by the IJF. As many as 28 Judo clubs out of all Indonesian Judo clubs were selected to be the sample in this study. The results showed that most of the clubs have been implementing the protocols by the IJF.
\end{abstract}

Keywords : Covid-19, Judo, health and safety protocols 


\section{PENDAHULUAN}

Pada bulan Desember 2019, keadaan darurat kesehatan masyarakat diakibatkan oleh merebaknya novel beta coronavirus yang dinamai 2019-novel coronavirus (SARS-CoV-2) yang akan menjadi pandemik di seluruh dunia dengan tingkat mortalitas yang tinggi (Pradhan et al., 2020). Virus ini adalah RNA coronavirus yang dikembangkan dan sebagian besar ditularkan dari orang ke orang (orang yang berada dalam kontak dekat satu sama lain atau tetesan pernapasan yang dihasilkan ketika orang yang terinfeksi batuk atau bersin) dan pada tingkat yang lebih rendah dari kontak dengan permukaan yang terkontaminasi atau benda (Pradhan et al., 2020). Penyakit ini tidak memandang letak geografis, penyakit ini mempunyai jangkauan yang global, menakutkan bagi semua lembaga kesehatan masyarakat (Parnell et al., 2020) Penyebaran Virus Corona atau Covid-19 sangat cepat, berawal di kota Wuhan, Provinsi Hubei, Cina. Virusnya cepat menyebar di seluruh negeri dan kemudian ke seluruh dunia ( $\mathrm{Zu}$ et al., 2020), menyebabkan pandemi yang belum pernah terjadi sebelumnya, pandemi ini memaksa pemerintah di hampir tiap negara untuk memberlakukan karantina. Covid-19 pertama kali masuk ke Indonesia pada awal bulan Maret 2020, karena penyebaran Covid-19 ini begitu cepat maka pemerintah mulai memberlakukan peraturan Work From Home dan Stay At Home. Para pekerja di arahkan untuk bekerja dari rumah atau work from home, dan anak anak sekolah di programkan untuk belajar dari rumah, pusat kebugaran olahraga di tutup (Yarımkaya \& Esentürk, 2020).Belum adanya vaksin ataupun obat yang secara spesifik dapat menyembuhkan penyakit ini, membuat potensi penyebaran secara global makin terbuka. Karena itu meminimalkan pertemuan secara massa baik acara musik,agama mataupun olahraga sangat mempengaruhi untuk terjadinya penyebaran secara global (Ebrahim et al., 2020). Oleh karena itu program acara olahraga yang dilaksanakan secara global dikhawatirkan akan meningkatkan potensi penyebaran penyakit ini. Acara olahraga terbesar yang tertunda karena penyebaran penyakit ini adalah piala EURO 2020 dan juga Olympiade 2020 di Tokyo. Terlepas dari tertundanya acara besar dalam dunia olahraga WHO mempersiapkan langkah langkah atau protokol yang harus dipatuhi apabila akan mengadakan pertemuan secara massal, (Ebrahim et al., 2020) mengidentifikasi langkah langkah yang harus dijalankan yaitu: Pembatalan atau penangguhan acara apabila dianggap akan menjadikan penyebaran penyakit ini secara massal, melaksanakan physical distancing untuk mengurangi kontak langsung, Pembatasan perjalanan, termasuk pengurangan penerbangan dan angkutan umum serta pembatasn rute tanpa mengurangi pelayanan penting, melakukan karantina di rumah. Tentu saja hal ini berimbas pada kegiatan olahraga yang biasa melibatkan banyak orang. Baik itu kegiatan pertandingan maupun kegiatan latihan di klub olahraga.

Memasuki masa Adaptasi Kebiasaan Baru (AKB) atau bahasa globalnya adanal memasuki masa New Normal, sejumlah aktivitas sudah dapat dijalankan dengan aturan aturan atau protokol kesehatan yang harus di patuhi oleh orang yang akan melakukan aktivitas. Pentingnya mengikuti aturan protokol kesehatan yang harus dilaksanakan selama menghadapi AKB adalah untuk mengurangi penyebaran virus Covid 19. Selalu memakai masker ketika diluar rumah, rajin mencuci tangan dan menjaga jarak, adalah 
protokol kesehatan yang wajib dipatuhi oleh setiap orang yang melakukan aktifitas di luar rumah. Pada masa AKB pemerintah sedang mempersipkan skenario untuk pemulihan kegiatan ekonomi, sekolah maupun kegiatan lainya (wisnubrata, 2020). Olahraga adalah salah satu sektor yang mulai melakukaan kegitana dimasa AKB ini, setelah hampir empat bulan diberlakukannya ketentuan stay at home oleh pemerintah Indonesia. Keuntungan dari melakukan olahraga dapat mengobati 26 penyakit berbeda (Pedersen \& Saltin, 2015). Pentingnya melakukan olahraga merupakan landasan untuk pencegahan dari penyakit kritis.

Untuk itu, diperlukan protokol kesehatan yang dapat mengatur penyelenggaraan olahraga. Internasional Judo Federation (IJF) sebagai organisasi yang menaungi olahraga Judo di seluruh dunia mengeluarkan protokol kesehatan yang dianjurkan untuk dilaksanakan oleh klub klub Judo di seluruh Dunia. Tujuannya adalah agar seluruh pejudo dapat melakukan latihan di Klub, tetapi harus tetap menjaga rambu rambu dan protokol kesehatan yang disesuaikan dengan gaya olahraga Judo. Beberapa Klub Judo di Indonesia telah melaksanakan latihan selama masa pandemi Covid 19 ini, yang menjadi pertanyaan pada penelitian ini adalah : Seberapa banyak Klub Judo di Indonesia yang sudah mengikuti Protokol Kesehatan yang telah dikeluarkan oleh IJF?

Judo yang berarti "cara lembut " awalnya diciptakan pada 1882 oleh Jigoro kano sebagai cara mendidik fisik, mental, dan moral di Jepang. Judo dikategorikan sebagai seni bela diri modern, yang kemudian berkembang menjadi olahraga Olimpiade. Olahraga Judo berasal dari olahraga jujitsu yang diubah oleh Jigoro Kano. Judo adalah bentuk penyempurnan dari jujitsu. Judo pada mulanya ditulis dengan dua huruf cina atau kanji dibaca judo. Kata judo terdiri dari dua suku kata yaitu Ju dan Do. Ju berati kelembutan atau gentleness atau memberi jalan atau giving way dan Do berarti jalan atau cara, yang berarti berarti cara yang lembut atau halus. Arti kelembutan disini ialah apabila seseorang yang lebih kuat mendorong saya dengan seluruh kekuatannya dan saya melawan dengan kekuatan saya maka tentu saya akan kalah atau jatuh, untuk bisa mengalahkannya, saya akan mundur atau melangkah kesamping sambil menarik orang tersebut searah dengan arah dorongannya sehingga dengan demikian orang tersebut akan kehilangan keseimbangannya ,pada saat itulah saya dengan mudah dapat melempar atau membanting dia dengan satu teknik lemparan.

Judo digunakan untuk membela diri dari suatu keadaan yang tidak diharapkan atau tidak menguntungkan, misalnya serangan yang tiba-tiba, berupa tendangan, pukulan, cekikan atau bantingan, bahkan dari serangan yang menggunakan senjata tajam. Tetapi tujuan judo sebenarnya lebih dari itu, yaitu membentuk karakter dan mental manusia seperti yang dijelaskan Jigoro Kano (1989, hlm. 20) sebagai berikut : "...it's aim is making the body strong, useful and healthy while building character through mental and moral discipline". Maksud dari pernyataan tersebut adalah membentuk badan menjadi kuat, berguna bagi kesehatan dan membentuk karakter melalui mental dan disiplin. Judo yang dijajarkan di Kodokan ( Tempat Judo pertama kali di ciptakan) ditulis dalam dua bentuk huruf Cina, kedua kata ju antara jujutsu dan judo memberikan pengertian yang sama yaitu lemah lembut atau memberikan jalan, jutsu 
bisa diartikan sebagai seni dan latihan, sedangkan $d o$ berarti prinsip atau cara yang menjadi konsep hidup diri sendiri. Jujitsu bisa diartikan sebagai seni yang "lemah lembut" dengan tujuan mengalah lebih dahulu untuk mencapai suatu kemenangan. Dalam olahraga judo, tujuan membanting lawan bukanlah untuk mencederai atau menghancurkan lawan. Dapat diambil kesimpulan bahwa judo itu adalah olahraga yang lembut, walaupun diperlukan kekuatan.

Prinsip- prinsip Judo yang dikemuakakan oleh Kano adalah seiryoku zen'yo ( efficiency, efisiensi maksimum dan upaya minimum) dan jita kyoei ( kesejahteraan dan manfaat bersama) yang artinya adalah melawan yang lebih kuat akan menghasilak kekalahan, sementara menyesuaikan diridan menghindari serangan lawan akan menyebabkan dia kehilangan keseimbangan , kekuatannya akan berkurang, dan akan bisa mengalahkannya. Kano menyadari bahwa seiryoku zen yo memiliki aplikasi filosofi yang lebih luas dalam membentuk perkembangan Judo.

Falsafah judo menetapkan bahwa dalam menghadapi lawan, keselamatan lawan (uke) harus dijaga, oleh karena itu waktu melakukan bantingan lawan tidak boleh dilepas agar tetap di kontrol karena melihat dari tujuan judo itu sendiri adalah bukan untuk mencederai atau menyakiti melainkan untuk tujuan olahraga, selain itu dalam judo harus pula mengandung unsur tata krama, seni yang indah, jiwa besar, sportif dan saling menghargai.

Klub tempat latihan atau di dalam istilah Judo adalah Dojo. Klub judo adalah tempat berkumpulnya pejudo untuk melaksanakan latihan. Klub merupakan fondasi dari pembinaan olahraga prestasi. Pejudo yang brelatih di klub bukan hanya melakukan latihan untuk tujuan prestasi, tetapi melakukan latihan Judo dengan tujuan meningkatkab kebugaran. Keberadaan klub sangat penting untuk para pejudo, dengan adanya klub Judo, maka pejudo dapat melakukan latihan. Pelaksanaan latihan di Klub tidak hanya mengajari Teknik dan Fisik dalam olahraga Judo, tetapi diajarkan juga etika dalam olahraga Judo, sehingga berlatih Judo tidak saja menjadikan sehat secara fisik, tetapi sehat secara Mental. Kodokan adalah Dojo pertama yang didirikan oleh Jigoro Kano, hingga kini Kodokan masih dianggap sakral oleh pejudo di dunia.

\section{METODE}

Metode penelitian yang peneliti gunakan adalah metode penelitian deskriptif. Penelitian ini bertujuan untuk mencari seberapa banyak jumlah klub yang berada di Indonesia melakukan latihan pada masa Pandemi Covid-19 dengan tetap mengikuti standar protokol yang dikeluarkan oleh IJF. Sehingga dalam penelitian ini kami tuangkan persentase jumlah klub Judo yang melakukan latihan, klub Judo yang melakukan latihan dengan menerapkan standar protokol kesehatan menurut IJF dan persentase item standar kesehatan yang dilakukan klub-klub Judo di Indonesia.

Populasi seluruh klub Judo yang terdapat di Indonesia. Sedangkan populasi yang digunakan berjumlah 28 klub Judo dengan teknik pengambilan sampling secara random sampling Yang dimaksud dengan teknik pengambilan sampling random sampling adalah teknik pengambilan sampling secara acak, dimana setiap anggota populasi memiliki kesempatan yang sama untuk dijadikan atau terpilih menjadi sample penelitian. Instrumen penelitian berupa angket mengenai protocol kesehatan yang dipublikasikan oleh IJF. 
Teknik analisis data menggunakan analisis deskriptif yaitu dengan langkahlangkah sebagai berikut:

1. Memasukan hasil angket kedalam excel

2. Hitung rata-rata-standar deviasi, skor maksimum, skor minum dan interval

3. Membuat rentang skor

4. Mengkategorikan kedalam lima jenis kategori yaitu Baik Sekali, Baik, Cukup, Kurang dan Kurang Sekali dan

5. Memasukkan skor perolehan tiap klub sehingga diketahui klub-klb tersebut berada pada kategori yang telah ditentukan. Kemudian analisis perolehan skor dari setiap butir soal. Sehingga didapatkan seberapa banyak klub yang melakukan protokol kesehatan sesuai dengan standar IJF.

\section{HASIL DAN PEMBAHASAN Hasil}

Hasil survey adaptasi latihan Judo pada masa pada masa pandemi Covid-19 ini dapat dilihat pada Gambar 1 (Klub yang melakukan latihan dan tidak), Gambar 2 (Persentase kategori klub yang melaksanakan protokol Covid-19), dan Gambar 3 (Hasil persentase item pelaksanaan protokol kesehatan).

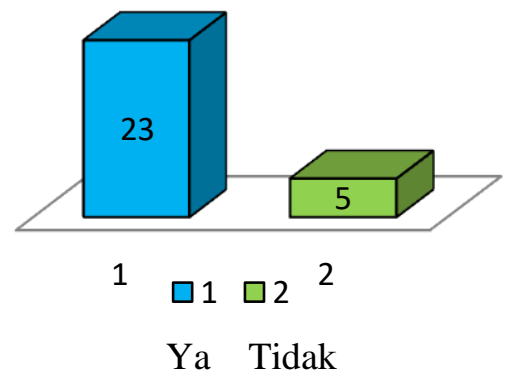

Gambar 1. Klub yang Melakukan Latihan Pada Masa Pandemi Covid-19
Gambar 1 menunjukan bahwa sebanyak 23 klub tetap melaksanakan latihan selama masa pandemi Covid-19 sedangkan 5 klub tidak melaksanakan latihan.

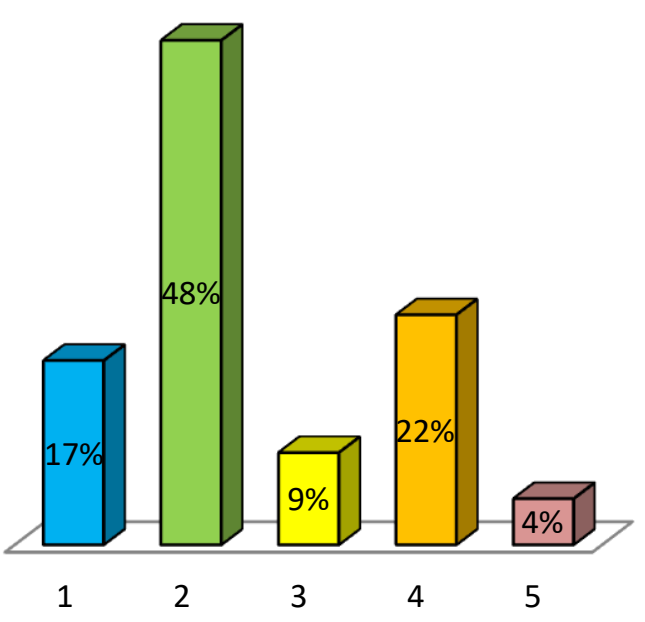

Gambar 2. Persentase Kategori

Pelaksanaan Protokol Covid-19

Gambar 2 menjelaskan mengenai persentasi kategori pelaksanaan protokol Covid-19 sebanyak 17\% berada dalam kategori Baik Sekali, $48 \%$ Baik, 9\% Cukup, 22\% Kurang dan sebanyak 4\% dalam kategori Kurang Sekali.

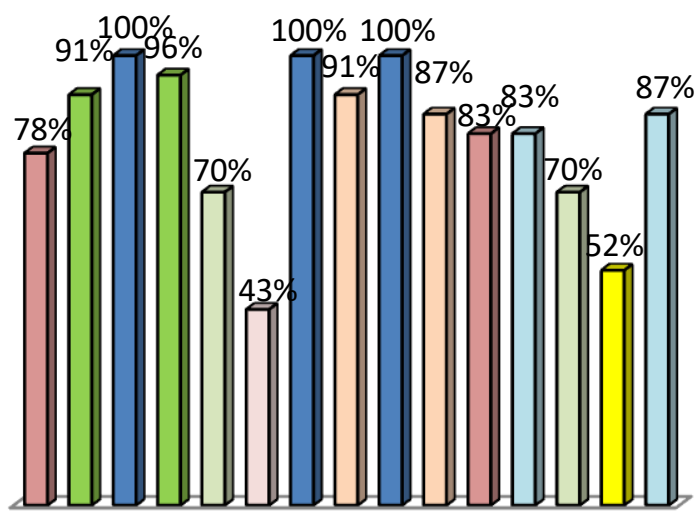

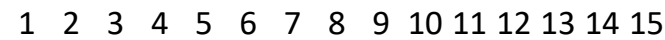

Gambar 3. Hasil Persentase Pelaksanaan Protokol Kesehatan IJF 
Pada Gambar 3 dapat disimpulkan bahwa protokol kesehatan no 3 (pelatih dan atlet menyimpan sepatu atau sandal yang dipakai dari luar di tempat yang jauh dari tatami atau disimpan di tempat tersendiri), 7 (pelatih dan atlet mencuci tangan sebelum melaksanakan latihan) dan 9 (apakah pelatih dan atlet menggunakan judogi yang bersih pada waktu latihan) merupakan protokol kesehatan yang setiap klub judo melaksanakannya.

\section{Pembahasan}

Judo adalah olahraga yang melibatkan lawan atau teman latihan untuk membanting tubuh ke udara, lalu memegang tubuhnya ke bawah. Judo juga merupakan pelatihan untuk melatih pikiran dan melatih tubuh yang paling efisien untuk keperluah hidup kita sehari hari (Nobuo, 2013). Judo adalah olahraga dengan menggunakan upaya minumum untuk mencapai efisiensi yang maksimum. Judo adalah olahraga yang menyenangkan dan mendebarkan yang dapat diminati oleh sagala kalangan, baik pria maupun wanita, usia muda dan tua. Judo adalah olahraga pertahanan diri atau beladiri. Didalam Judo terdapat moral dan etika yang dipelajari selain meningkatkan kondisi fisik tubuh. Dengan penjelasan ini, dapat dilihat bahwa Judo adalah salah satu olahraga pilihan yang dapat dilakukan selama masa pandemi Covid 19 ini.

$$
\text { Latihan Judo biasanya }
$$

dilaksanakan di Klub. Pada masa pandemi Covid 19 ini, tidak semua klub melaksanakan latihan, seperti yang di dapatkan dari data bahwa 5 daerah tidak melaksanakan latihan pada masa pandemic ini, alasannya dikarenakan ada beberapa daerah yang masih termasuk kedalam zona merah. Ini berarti bahwa penyebaran Covid 19 dalam batas tinggi. Sehingga pengurus dan pelatih klub tidak berani untuk melaksanakan latihan Judo, karena di khawatirkan akan menimbulkan penyebaran dari penyakit Covid 19. Salah satu contoh Klub Judo yang tidak melaksanakan latihan adalah Klub Judo dari kota Makassar , dari data yang diambil pada saat artikel ini di tulis data yang terinfeksi Covid 19 di provinsi Sulawesi selatan adalah 7630 orang, tentu saja hal ini sangat meresahkan, sehingga membuat masyarakat di Makassar harus berhati hati untuk melakukan aktifitas diluar rumah. Salah satu yang diwaspadai adalah berlatih Judo, dikarenakan dalam latihan Judo kita memerlukan partner atau lawan untuk dapat berinteraksi (Berkovich et al., 2016). Untuk 23 Klub yang melaksanakan latihan pada masa pandemic ini dikarenakan, situasi daerah masih memungkinkan untuk melaksanakan latihan karena pada saat artikel ini ditulis masih dalam zona kuning dan hijau, sehingga pelatih berani untuk melaksanakan latihan pada masa pandemic covid-19 ini. Dengan menjalakan latihan Judo diharpakan agar imun tubuh meningkat dan bisa mencegah tertularnya virus Covid-19.

Untuk Klub Judo yang melaksanakan latihan selama masa pandemi Covid 19 ini, diharapkan untuk dapat mengikuti panduan protokol kesehatan yang dikeluarkan oleh IJF. Tata cara, Protokol kesehatan yang dikeluarkan IJF adalah:

1. Mandi sebelum datang ke dojo

2. Menempatkan alas kaki di luar tatami

3. Lokasi ganti baju di tempat yang terpisah

4. Durasi selama melaksanakan latihan

5. Mengunakan masker apabila klub berada di daerah yang termasuk zona merah atau hitam

6. Mencuci tangan sebelum memasuki dojo 
7. Mencuci kaki sebelum masuk tatami

8. Menggunakan Judogi dan pakaian olahraga yg bersih sebelum latihan

9. Tatami dibersihkan menggunakan disinfetan sebelum dan sesudah melaksanakan latihan

10. Pengukuran suhu tubuh sebelum latihan

11. Peralatan latihan dipastikan sudah dibersihkan menggunakan disinfektan

12. tanda/ marka untuk masuk dan keluar dojo, disertai dengan memperhatikan jarak keamanan dan jarak sanitasi di dojo.

13. Jarak antara atlet masing masing 2 meter pada saat latihan

14. Kehadiran dari pejudo disesuaikan dengan peraturan pemerintah setempat

Dari hasil analisis data, ditemukan bahwa seluruh klub yang melaksanakan latihan pada masa pandemi Covid 19 ini, mentaati protokol kesehatan yang mengharuskan menyimpan alas kaki di luar tatami, dan juga mencuci kaki sebelum masuk tatami. Sesuai dengan aturan yang telah diberlakukan di banyak tempat, bahwa menjaga kebersihan adalah salah satu kunci untuk mengurangi penyebaran penyakit ini. Kaki adalah salah satu anggota tubuh yang dapat membawa kotoroan, oleh sebab itu penepatan alas kaki harus berada diluar tatami, agar kotoran yang terbawa dar jalan tidak menempel di tatami. Begitu pula dengan mencuci kaki, agar kotoran yang menepel di kaki tidak masuk ke tatami, maka pejudo diharuskan mencuci kaki sebelum masuk tatami, untuk menjaga kebersihan tatami.

Hampir seluruh protokol kesehatan dari IJF dilaksanakan oleh Klub yang melakukan latihan pada masa pandemi Covid 19, seperti mandi sebelum melaksanakan latihan, memakai pakaian dan judogi yang bersih, tempat untuk berganti pakaian berada ditempat yang berbeda dengan tatami,mencuci tangan, membersihan tatami dengan disinfektan, dan membersihkan alat alata yang akan digunakan utuk latihan, keseluruhan item dari protokol kesehatan IJF telah dilaksanakan oleh Klub Judo. Kesadaran pejudo mengikuti protokol kesehatan dikarenakan kekhawatiran penyebaran dari penyakit ini. Penggunaan masker pada saat latihan adalah item yang di ikuti oleh peserta latihan pada klub Judo. Hal ini memperlihatkan bahwa pejudo telah menyadari bahwa penggunaa masker adalah salah satu langkah penting untuk mengurangi penyebaran penyakit Covid 19 (Nur Rohim Yunus \& Annissa Rezki, 2020) . Tujuan dari penggunaan masker adalah agar menghindari penularan yang dapat terjadi karena droplet. Dengan penggunaan masker ini droplet yang keluar melalui mulut dapat terhambat. Oleh karena itu salah satu protokol kesehatan yang harus ditaati adalah penggunaan masker. Mengatur jarak antar Pejudo pada saat latihan adalah item yang banyak dilaksanakan oleh pejudo, aturan ini diambil atas dasar, bahwa penyeberan penyakit ini dapat di minimalisir dengan adanya physical distancing (Chen et al., 2020). Jarak yang harus di patuhi oleh pejudo untuk melaksanakan physical distancing adalah 2 meter.

Lama latihan yang dilaksanakan rata rata selama 2 jam, dengan intensitas sedang. Waktu latihan ini termasuk dari pemanasan, inti dan pelemasan. Pemanasan terdiri dari stretching statis, streyching dinamis, senam Judo, untuk latihan inti berisi, Uchikomi, Nage Waza dan Randori, lalu di lanjutkan dengan pelemasan. Latihan di daerah yang masih berada di zona hitam atau merah, rekomendasi dari IJF adalah dilarang untuk melakukan Randori dan Uchikomi yang bersifat adanya physical 
contact, latihan yang disarankan oleh IJF adalah latihan tendoku renshu atau latihan secara indvidual, lalu melatih tachi waza, newaza, ukemi secara Individual. Langkah ini di berikan agar pejudo tetap bisa berlatih tetapi faktor kesehatan harus tetap terjaga. Protokol kesehatan dari IJF ini disesuaikan dengan keadaan klub atau tempat berlatih judo, apabila klub berada di zona hijau, pelaksanaan latihan dapat dilaksanakan seperti biasa, dengan memperbolehkan pejudo melakukan uchikomi dan randori. Tetapi apabila klub berada di zona yang masih membahayakan, maka anjuran dari IJF tidak boleh ada kontak fisik dan harus menjalankan physical distancing.

Dampak psikologis dari pandemic Covid-19 tehadap latihan di 23 Klub Judo yang melaksanakan latihan adalah pelatih dan atlet mengalami sedikit kecemasan, karena pelaksanaan latihan harus betul betul dilaksanakan sesuai dengan protokol kesehatan yang di keluarkan IJF, agar pelaksanaan latihan Judo di Klub memberi dampak psikologis yang positif dan dapat meningkatkan imun dari pejudo yang melaksanakan latihan.

\section{SIMPULAN DAN SARAN}

Dari hasil penelitian dan pembahasan dapat disimpulkan bahwa Klub Judo yang melaksanakan latihan pada masa pandemi Covid 19 ini , melaksanakan latihan dengan mengikuti protokol kesahatan yang dikeluarkan oleh IJF. Kesadaran akan pentingnya melaksanakan protokol kesehatan sangat penting, agar penyakit Covid 19 ini tidak menyebar secera terus menerus. Salah satu caranya adalah dengan mentaati protokol kesehatan yang telah dikeluarkan oleh pemerintah, ataupun protokol kesehatan yang dikeluarkan oleh induk organisasi olahraga. Selalu berolahraga agar kebugaran selalu terjaga.

\section{DAFTAR PUSTAKA}

Barene, S., Holtermann, A., Oseland, H., Brekke, O. L., \& Krustrup, P. (2016). Effects on muscle strength, maximal jump height, flexibility and postural sway after soccer and Zumba exercise among female hospital employees: a 9-month randomised controlled trial.

Journal of Sports Sciences, 34(19), 1849-1858.

https://doi.org/10.1080/02640414.2 016.1140906

Berkovich, B., Eliakim, A., Nemet, D., Stark, A. H., \& Sinai, T. (2016). Rapid Weight Loss Among Adolescents Participating In Competitive Judo. 276-284.

Chen, S., Yang, J., Yang, W., Wang, C., \& Bärnighausen, T. (2020). COVID-19 control in China during mass population movements at New Year. In The Lancet (Vol. 395, Issue 10226, pp. 764-766). Lancet Publishing Group. https://doi.org/10.1016/S01406736(20)30421-9

Ebrahim, S. H., Ahmed, Q. A., Gozzer, E., Schlagenhauf, P., \& Memish, Z. A. (2020). Covid-19 and community mitigation strategies in a pandemic. In The BMJ (Vol. 368). BMJ Publishing Group. https://doi.org/10.1136/bmj.m1066

Hammami, A., Harrabi, B., Mohr, M., \& Krustrup, P. (2020). Physical activity and coronavirus disease 2019 (COVID-19): specific recommendations for home-based physical training. Managing Sport and Leisure, $0(0), 1-6$. https://doi.org/10.1080/23750472.2 020.1757494 
Nobuo, H. (2013). Journal of Health, Physical Education, Recreation. April 2015, 37-41. https://doi.org/10.1080/00221473.1 957.10627825

Norouzi, E., Hosseini, F. S., Vaezmosavi, M., Gerber, M., Pühse, U., \& Brand, S. (2019). Zumba dancing and aerobic exercise can improve working memory, motor function, and depressive symptoms in female patients with Fibromyalgia. European Journal of Sport Science. https://doi.org/10.1080/17461391.2 019.1683610

Nur Rohim Yunus, \& Annissa Rezki. (2020). Kebijakan Pemberlakuan Lockdown Sebagai Antisipasi Penyebaran Corona Virus Covid19 .

https://doi.org/10.15408/sjsbs.v7i3. 15083

Parnell, D., Widdop, P., Bond, A., \& Wilson, R. (2020). COVID-19, networks and sport. Managing Sport and Leisure, 1-7. https://doi.org/10.1080/23750472.2 020.1750100

Pedersen, B. K., \& Saltin, B. (2015). Exercise as medicine - Evidence for prescribing exercise as therapy in 26 different chronic diseases. Scandinavian Journal of Medicine and Science in Sports, 25, 1-72. https://doi.org/10.1111/sms.12581

Pradhan, P., Pandey, A. K., Mishra, A., Gupta, P., Tripathi, P. K., Menon, M. B., Gomes, J., Vivekanandan, P., \& Kundu, B. (2020). Uncanny similarity of unique inserts in the 2019-nCoV spike protein to HIV-1 gp120 and Gag. BioRxiv, 2020.01.30.927871. https://doi.org/10.1101/2020.01.30. 927871

wisnubrata. (2020). Menyongsong "New Normal", Apa yang Bisa Kita Lakukan? Halaman all Kompas.com.

Yarımkaya, E., \& Esentürk, O. K. (2020). Promoting physical activity for children with autism spectrum disorders during Coronavirus outbreak: benefits, strategies, and examples. International Journal of Developmental Disabilities, O(0), $1-6$.

https://doi.org/10.1080/20473869.2 020.1756115

Zu, Z. Y., Jiang, M. Di, Xu, P. P., Chen, W., Ni, Q. Q., Lu, G. M., Zhang, L. J., Hospital, J., Hospital, T., Zu, D., Zhang, L. J., Clinical, N., \& District, X. (2020). Coronavirus Disease 2019 (COVID-19): A Perspective from China Zi. JAMA Journal of the American Medical Association, 2019, in press. 